\title{
حماية البيئة من التصحر - در اسة فقهية مقارنة بالتشريعات البيئية العربية
}

محمد محمد سيد أحمد عامر 1*

ا كلية الثريعة والقانون بالقاهرة - جامعة الأزهر

Received: 24 May 2015 / Accepted: 17 August 2015

*Corresponding author: nabil_hama@yahoo.fr

\section{ملخص}

مشكلة البحث : تثشير الاراسات والإحصائيات المحلية والدولية إلى تنامي ظاهرة التصحر على المئل الميتوى العالمي والعربي

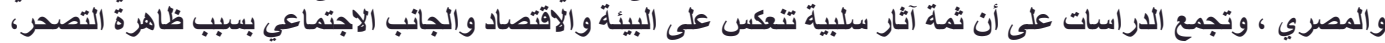

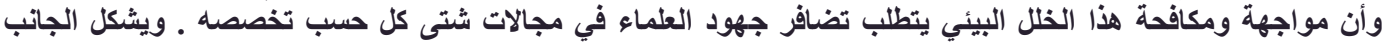

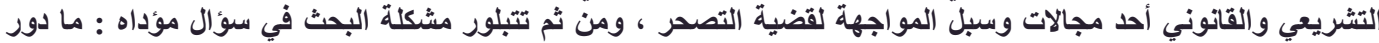

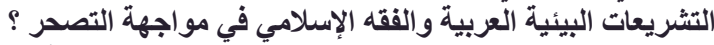

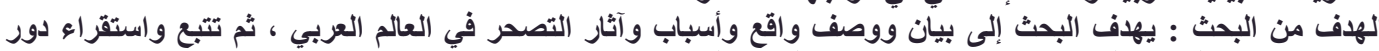

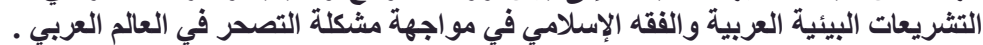

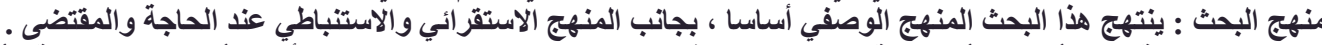

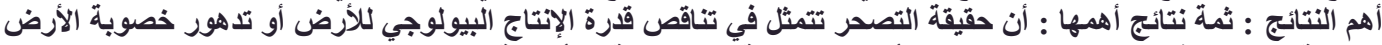

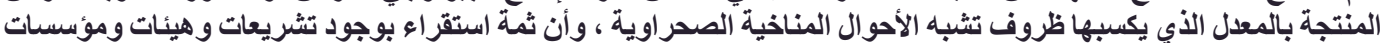

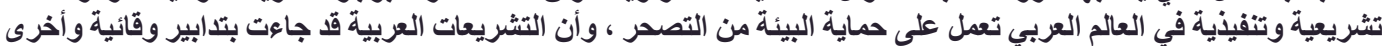

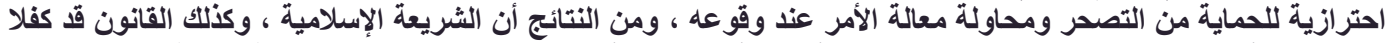

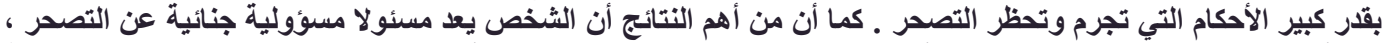

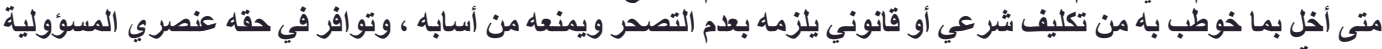

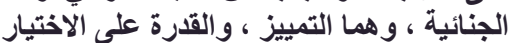

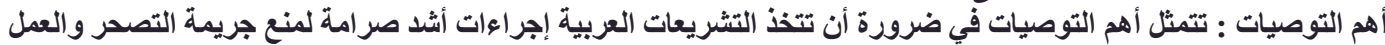

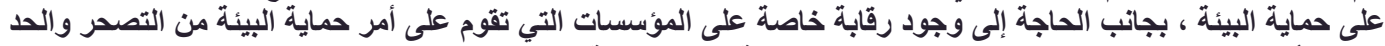

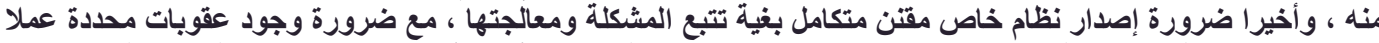

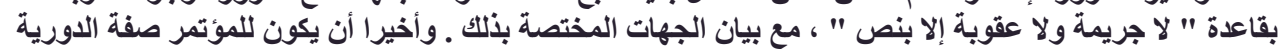

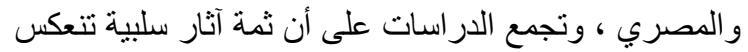

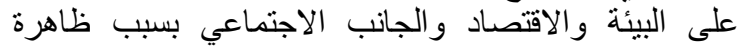

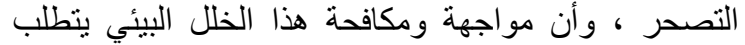

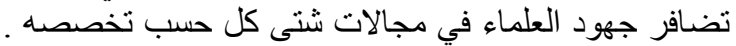

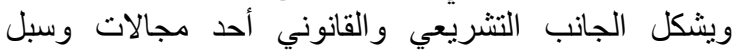
المواجهة لقضية التصحر ، ومن ثم تتبلور مشكلة البحث في التي

تشير الدراسات و الإحصائيات المحلية و الدولية إلى الى ولى

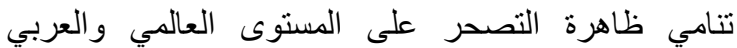




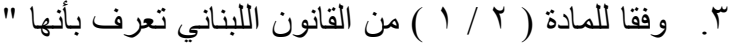

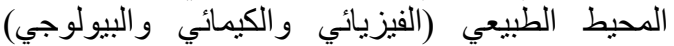
و الاجتماعي الذي تعيش فيه الكائنات الحية " .

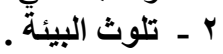

يقترب مفهوم التلوث من لفظ الجو ائح ، و الذي عرفه الإمام عطاء بأنه " كل ظاهر مفسد من مطر أو برد أو جر اد أو ريح الإمايح

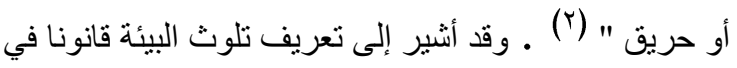

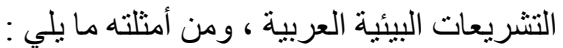

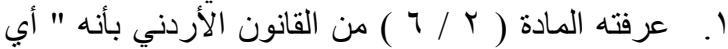

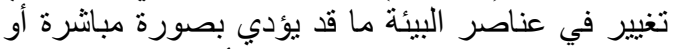

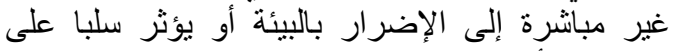
عناصر ها أو يؤثر على ممارسة الإضرار الإنسان لحياته الطبيعية الطية

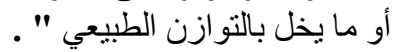

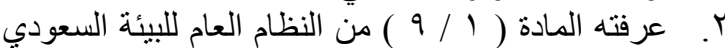

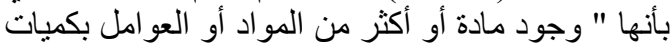

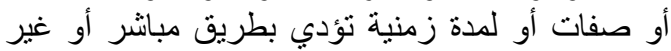

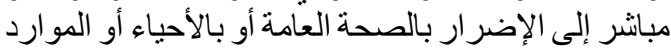
الطبيعية أو الممتلكات أو تؤثر سلبا على نوعية الإنيات الحياة ورفاهية الإنسان " .

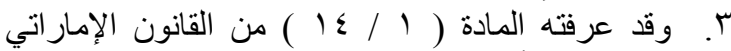

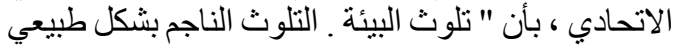

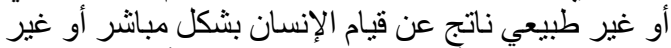

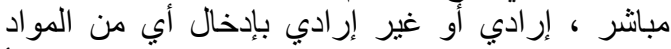

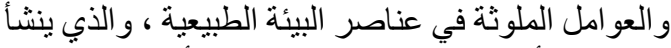

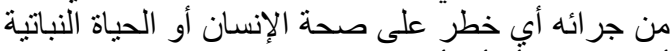
أو الحيو انية أو أي أذى للمو ارد و النظم البيئية " .

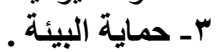

وثمة تعريفات لحماية البيئة قانونا في التشريعات البيئية العربية ، ومن أمثلتها ما يلي : العينة

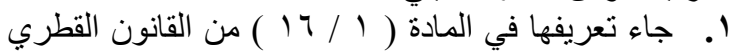

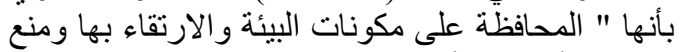

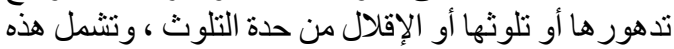

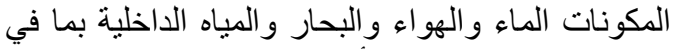
ذللك المياه الجوفية والأراضي واليحاء والدحميات الطبيعية

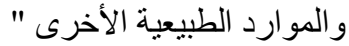

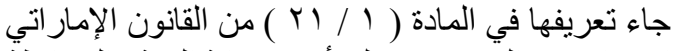

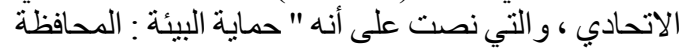

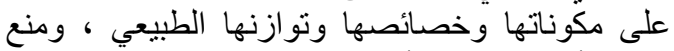

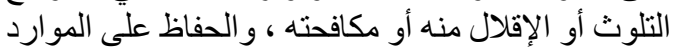

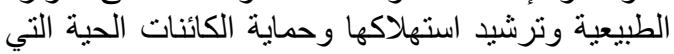

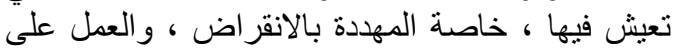

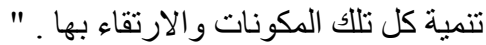

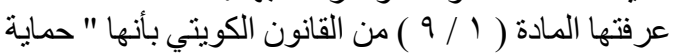

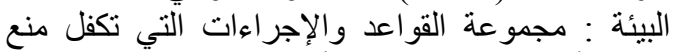

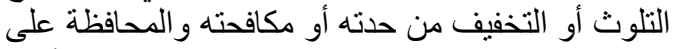
البيئة وماردها الطبيعية والتنو ع البيولوجي والتئه وإعادة تأهيل

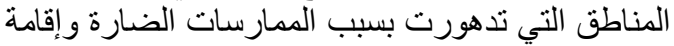
المحميات البرية والبحرية وتحديد مناطق عازلة التئلة حول

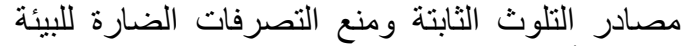
وتثبيع أنماط السلوك الإيجابي ". ع - التنمية المستدامة . وقد ورد تعريف التنمية المستدامة قانونا في التشريعات البيئية

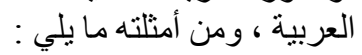
1. عرفتها المادة ( / / /. ) من القانون الليبي بأنها "التنمية

\author{
سؤ ال مؤداه : ما دور التشريعات البيئية العربيةو الفقه الإسلامي

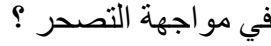

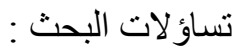

تتبلور مشكلة البحث في سؤال رئيس مؤداه : ما دور

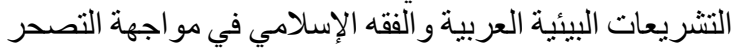

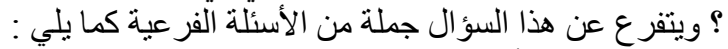

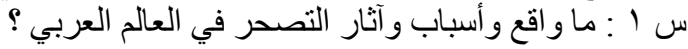
س ץ : ما دور التشريعات العربية البيئية في الحماية من العنار

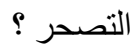
س ץ : ما موقف ودور الفقه الإسلامي في الحماية من التصحر؟

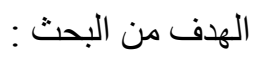

بهدف البحث إلى ما يلي :

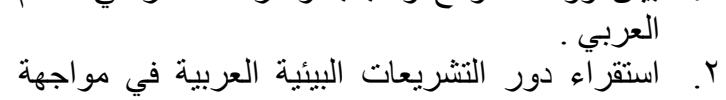

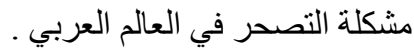

$$
\begin{aligned}
& \text { r. بيان موقف الفقه الإسلامي ودوره في الحماية من }
\end{aligned}
$$

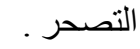

$$
\begin{aligned}
& \text { منهج البحث : }
\end{aligned}
$$

ينتهج هذا البحث المنهج الوصفي أساسا ، بجانب المنهج

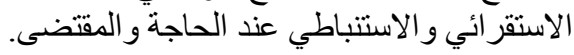

مصطلحات الدر اسة : - مصن

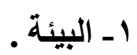

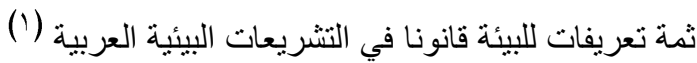

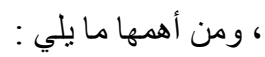

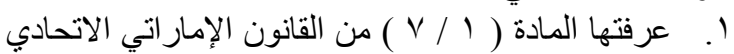

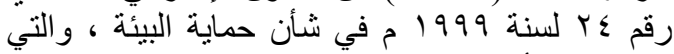

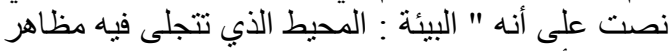
الحياة بأثكالها المختلفة ، وينكون هذا المحيط من فئل

عنصرين : طبيعي يضم الكائنات الحية من إنسان وحيوان

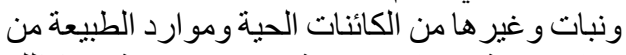

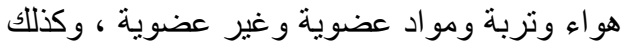
الأنظمة الطبيعية .

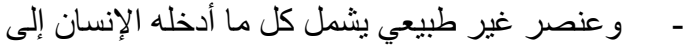

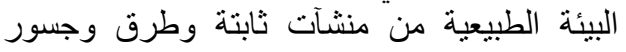
ومطار ات ووسائل نقل وما استحدثه من صنات وناعات

$$
\text { و مبتكرات وتقنيات " . }
$$

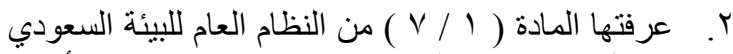

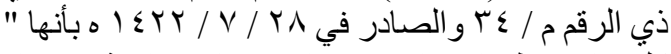

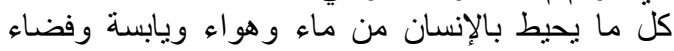

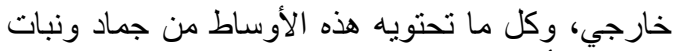
وحيو ان و أنكال مختلفة من طاقة ونظم و عمليك لأوسات طبيعية

$$
\text { و أنشطة بشرية " . }
$$


ثمة مؤشرات وظواهر تدل على تعاظم ونزايد مشكلة

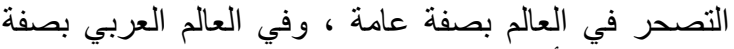

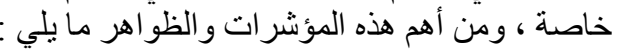

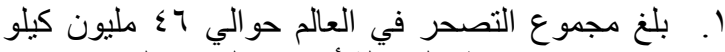

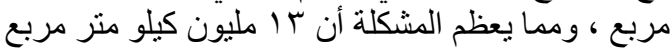

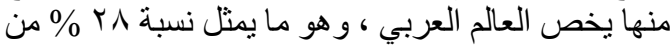

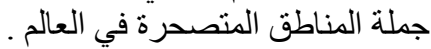
r. أن قرابة • ب \% من الأر اضي على سطح الكرة الأرضية

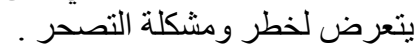

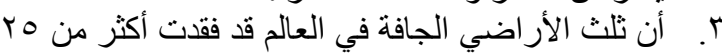
\% من قدرتها الإنتاجية .

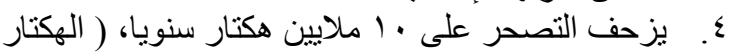

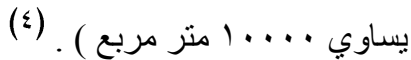

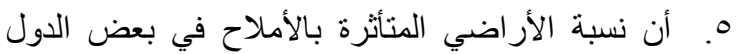

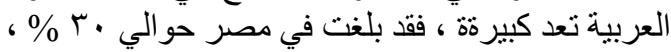

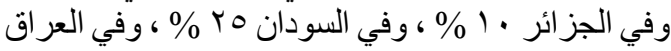

$$
\text { (c). \% } 0 \text {. }
$$

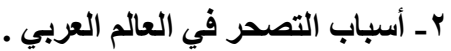

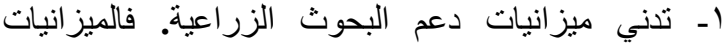

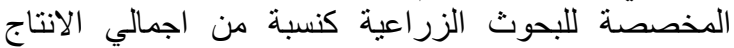

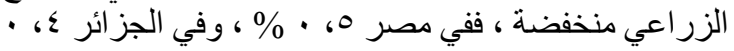

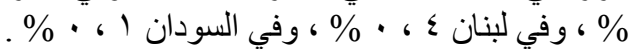

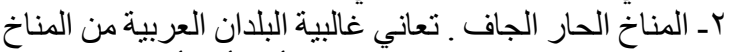

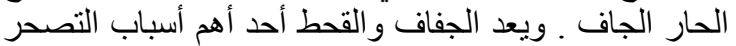

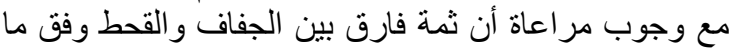

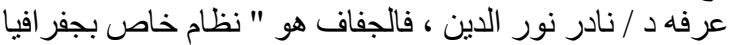

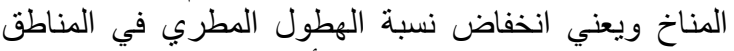

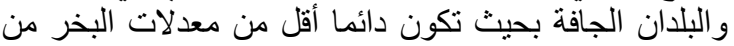

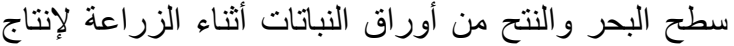

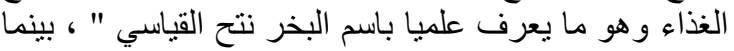

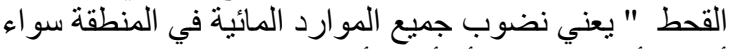

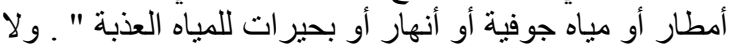

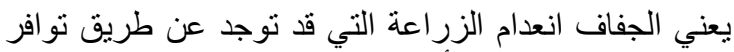

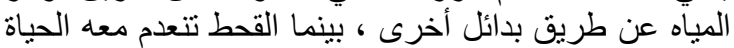

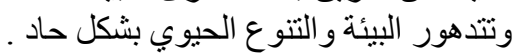

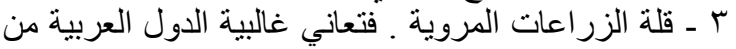

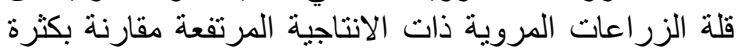

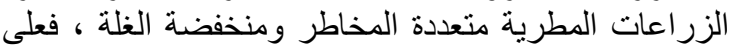

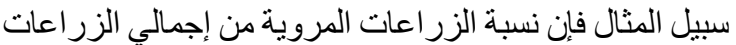

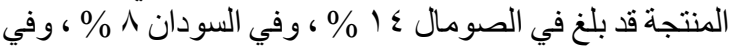

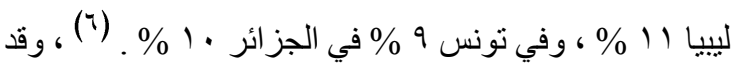

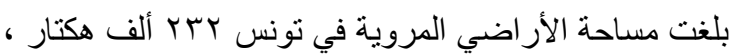

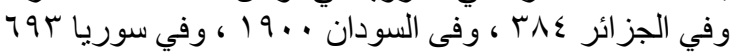

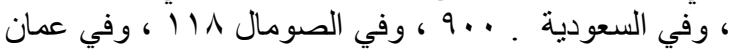

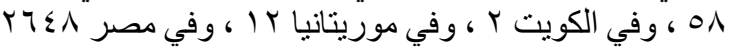

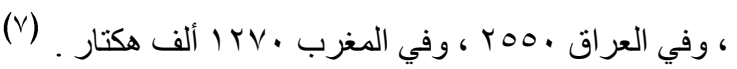

المستدامة : التنمية التي تحقق احتياجات أجيال الحاضر

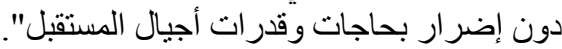

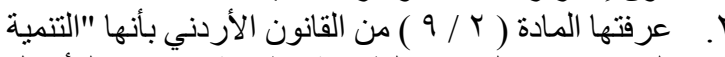

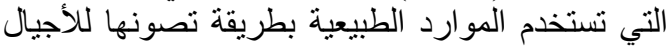

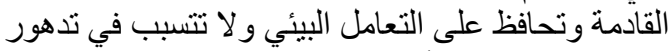

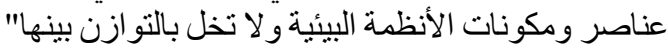

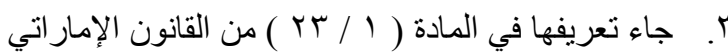

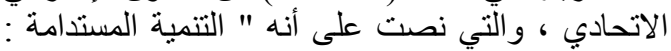

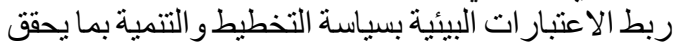

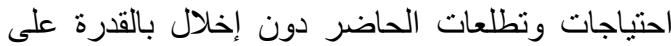
تحقيق احتياجات وتطلعات المستقبل . . تونيات

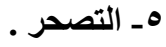
إن حقيقة التصحر تتمثل في تناقص قدرة الإنتاج البيولوجي

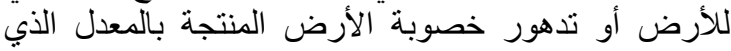
يكسبها ظروف تثبه الأحو ال المناخية الصحر اوية (r) خطة البحث: : - (

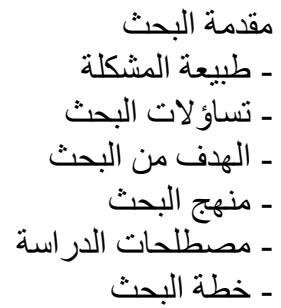
المبحث الأول : واقع وأسباب وآثار التصحر في العالم العربي

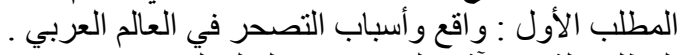

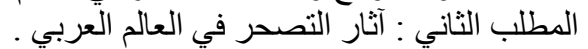

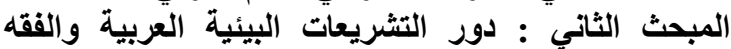

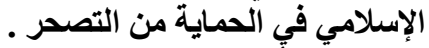

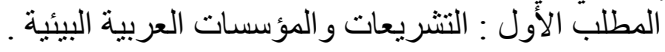

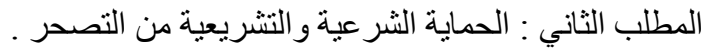

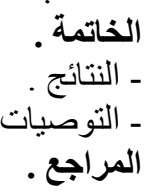

\section{المبحث الأول: واقع وأسباب وآثار التصحر في

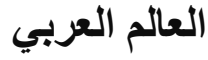

ثمة حاجة داعية لبيان و اقع التصحر في العالم العربي ، وذللك

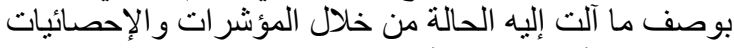

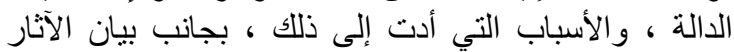

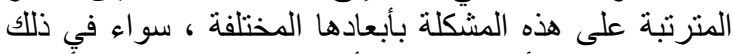

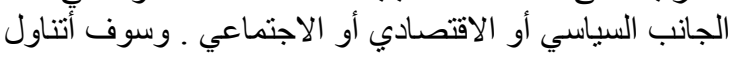
ذللك في مطلبين كما يلي : المطلب الأول: و اقع وأسباب التصحر في العالم العربي 1 - ـ و اقع التصحر في العالم العربي 


\begin{tabular}{|c|c|c|}
\hline 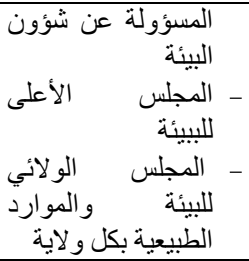 & رقم ^ا لعام I+.'Y & \\
\hline - مجل - مجلس حماريةة البيئة البيئة & - & سوريا \\
\hline - للبيئة المجلس م المحميات & 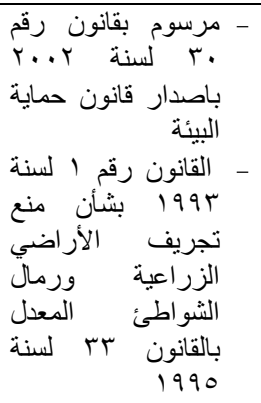 & قطر \\
\hline - ـ وزارة التنمية الريفية & 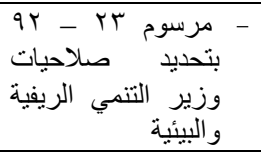 & موريتانا \\
\hline - الهيئة العامة للتنمية & 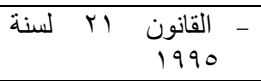 & الكويت \\
\hline - الليئة - وزلسة البيئة $\quad$ الوطني & 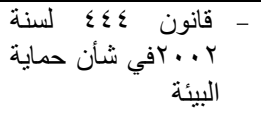 & لبنان \\
\hline - - الجهة المختصة البيئة & 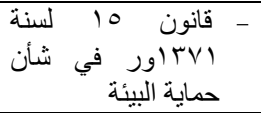 & ليبيا \\
\hline 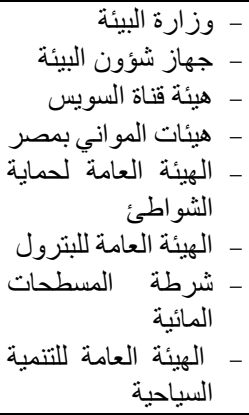 & 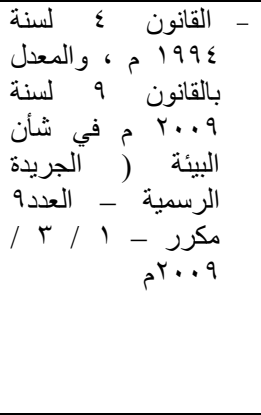 & مصر \\
\hline - - مجلس حماية البيئة & - قرقم بو لعام حماية البيئة & اليمن \\
\hline & 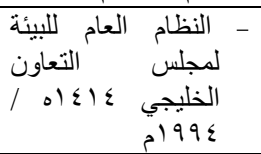 & الخليجي \\
\hline & - التنمية الإعلان العربي عن المستة & العامعة \\
\hline
\end{tabular}

المطلب الثاني: الحماية الثر عية و التشريعية من التصحر

إن مواجهة ومكافحة التصحر تتطلب تضافر الجهود في

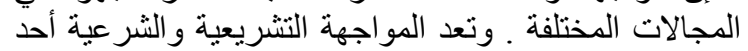

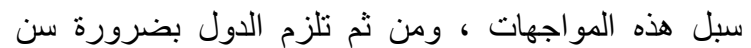

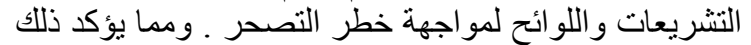

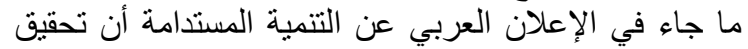

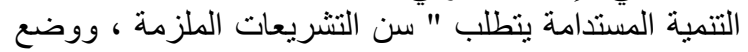

المطلب الثاني: آثار التصحر في العالم العربي

1 - حدوث المجاعات ـ ذللك أن القحطو الجفاف و التصحر يؤدي

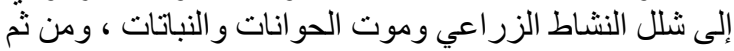

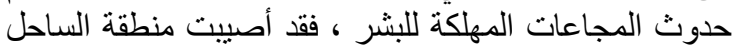

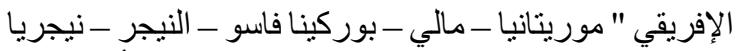

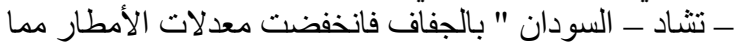

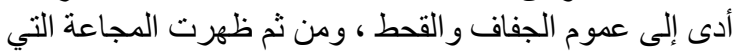

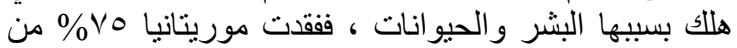

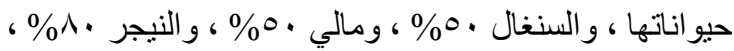
وتشاد • 9\% ، كما انخفض الإنتاج الزئر اعي في منطقة الساحل

الإفريقي إلى هم\% من طاقته الإنتاجية . (^)

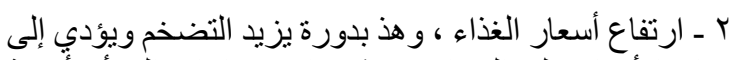

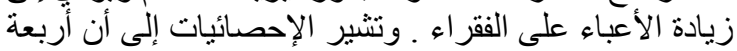

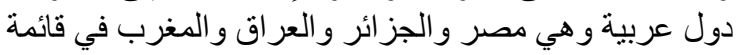

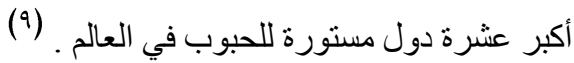

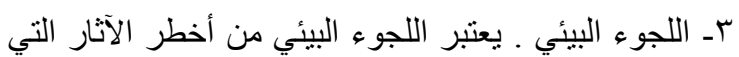

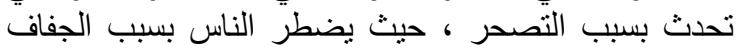

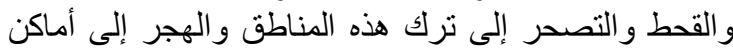

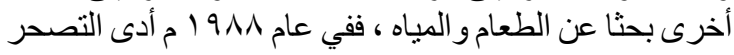

إلى وجود نحو · ا ملايين لاجئ بيئي . (·) (1)

\section{المبحث الثاني: دور التشريعات البيئية العربية و الفقه الإسلامي في الحماية من التصحر}

المطلب الأول: التشريعات و المؤسسات العربية البيئية

لاشك أن مو اجهة التصحر في حاجة إلى نشريعات وقو انين

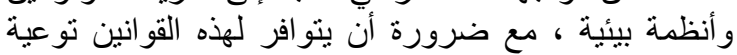

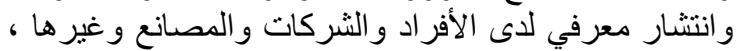

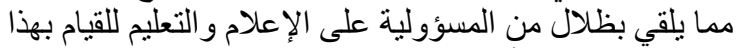

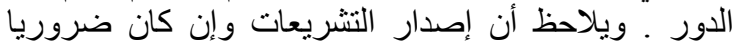

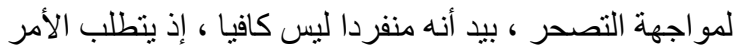

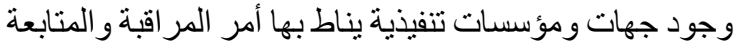

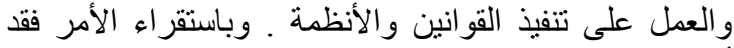

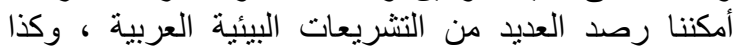

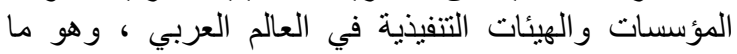
يصوره الجدول التالي : (1')

جدول ( 1 ) : يوضح أهم التشريعات و المؤسسات البيئية العربية

\begin{tabular}{|c|c|c|}
\hline أهم المؤسسات البيئية & أَهم التشريعات البيئية & الدولة \\
\hline 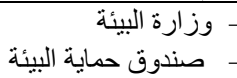 & 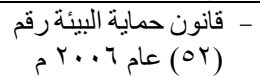 & الأردن \\
\hline ـــــالهيئة الاتحادية للبيئة & 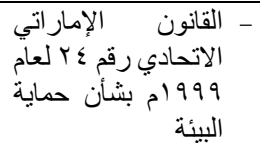 & الإمارات \\
\hline ـ محماية البيئة الأرصاد & 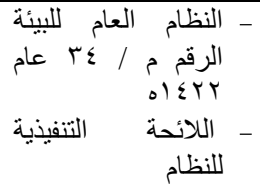 & السعودية \\
\hline ــ الوزارة & ـ قانون حماية البييئة & السودان \\
\hline
\end{tabular}


و التدابير اللازمة لحماية البيئة ومكافحة التلوث و المحافظة

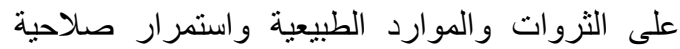

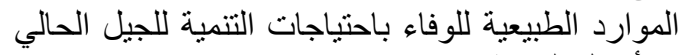

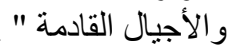

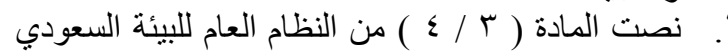

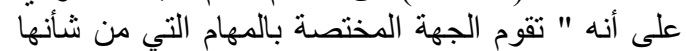

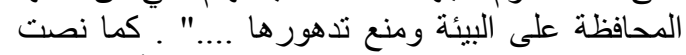

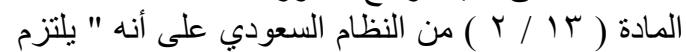

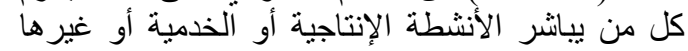

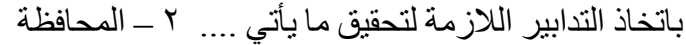

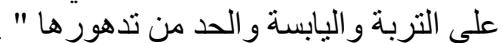

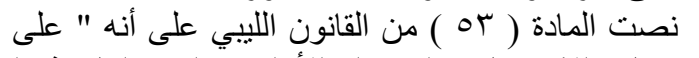

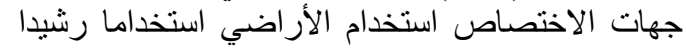
وفقا للظروف المحلية وتحسين التربة وزيادية الأية الحياة النباتية

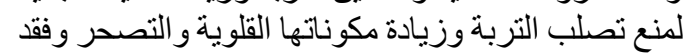

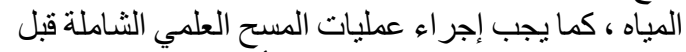

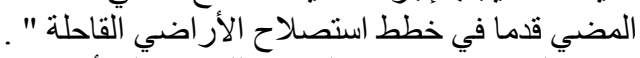

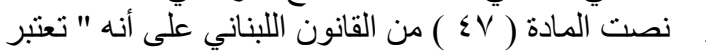

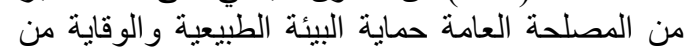

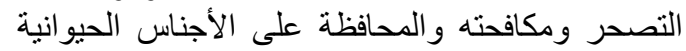

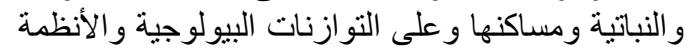
البيئية وعلى التنوع البيولوجي في مواجئية التوان كل أسباب

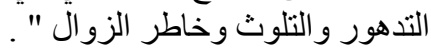

الفرع الثاني: التدابير الوقائية للحماية من التصحر التدابير الوقائية الثر عية للحماية من التصحر. يجب على الحاكم وفقا للإسلام أن يتخذ التدابير الوقائية التي

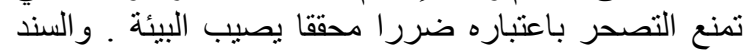

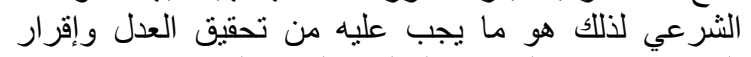

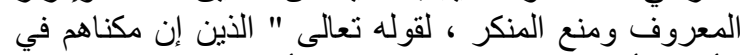

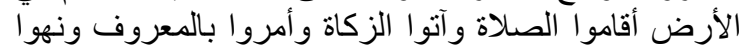
عن المنكر " (1) ) . كما أن القواعد الفقهية والثرعية تبرهن

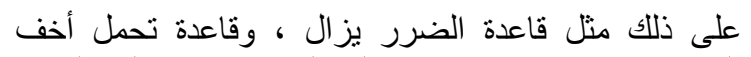

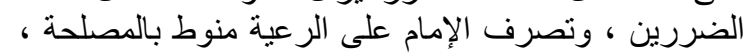

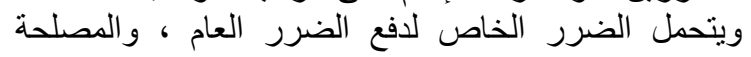

المرسلة . (19)

التدابير الوقائية في التشريعات البيئية العربية للحماية من التصحر

إن مبدأ الوقاية خير من العلاج يمثل فلسفة هامة بالنسبة

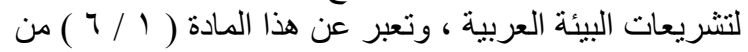

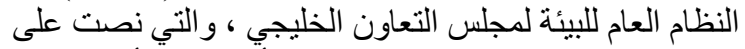

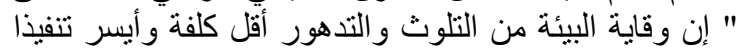

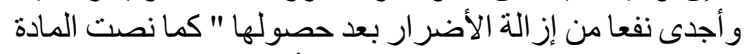

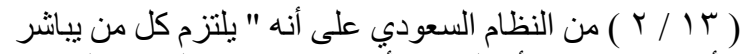

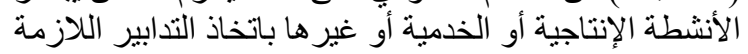

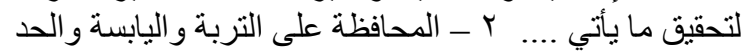

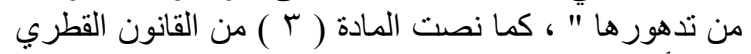

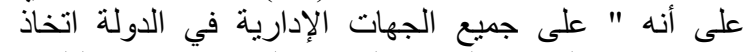

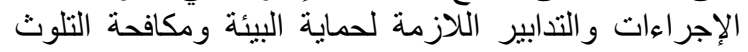

وتتفيذ السياسات المتكاملة على الصعيدين الوطني والإقليمي

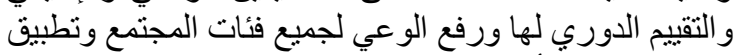

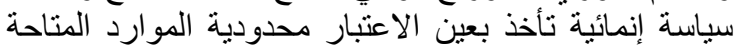

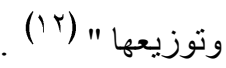

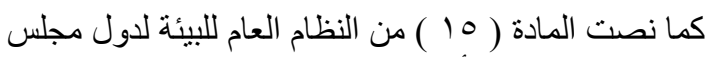

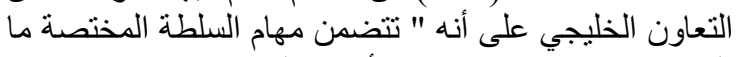

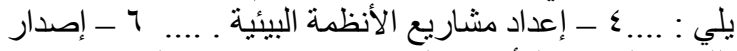

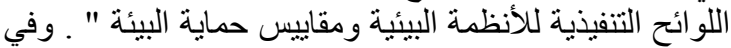

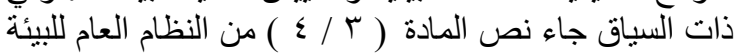

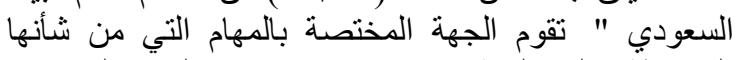

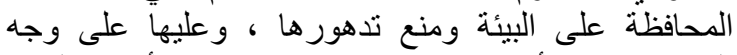

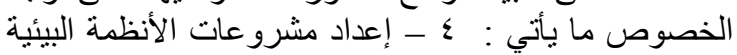

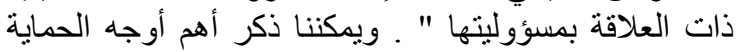

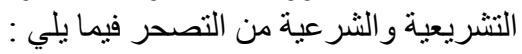

الترع الأول: الوجوب الثرعي و التشريعي للحماية من

$$
\text { الوجوب الشر عي للحماية من التصحر }
$$

يرفض الإسلام التصحر مع ما يترتب عليه من أثنار سلبية

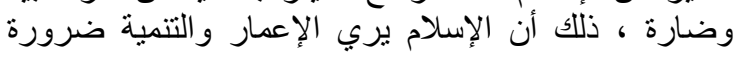
وو اجبا شر عيا (r آ) للأدلة التالية : ا. قوله تعالى " هو أنشأكم من الأرض واستعمركم فيها "

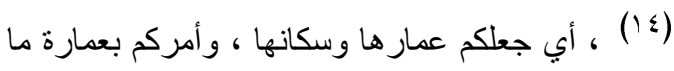

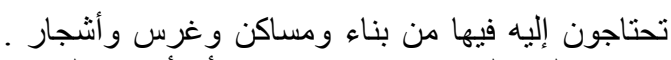

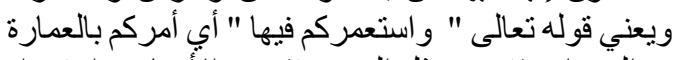

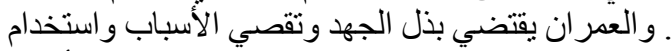
كل الوسائل اللازمة للتنمية و القضاء على لقي معو قاتهاو أهمها التصحر (10). وقد عقد الجصاص عند الحديث عن هذه

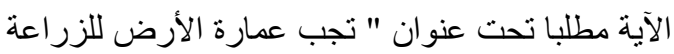

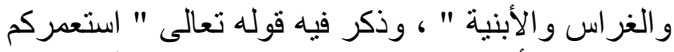

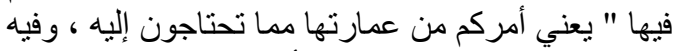

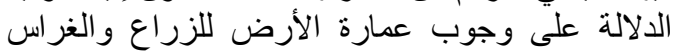

$$
\text { والأبنية (7 الالة على }
$$

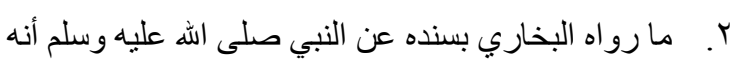

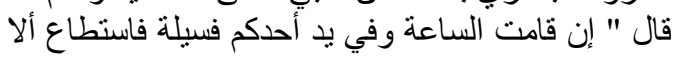
تقوم الساعة حتى يغرسها فليغرسها فله بذلك أجر " (IV)

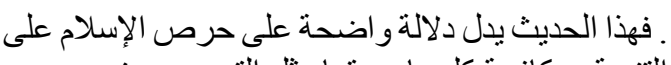

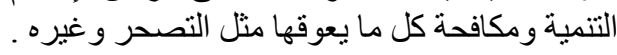

$$
\text { الوجوب التشريعي للحماية من التصحر }
$$

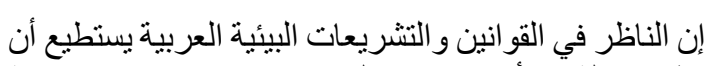

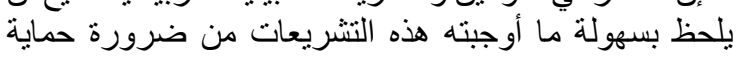

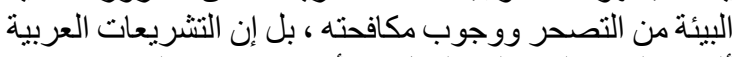

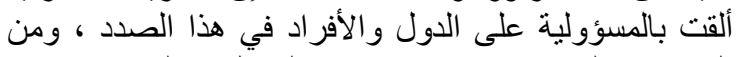

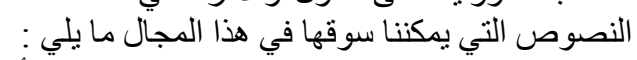

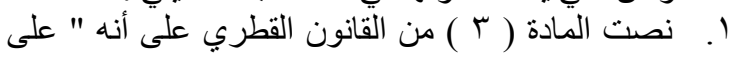

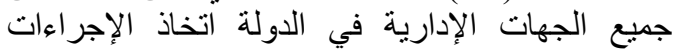




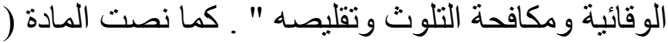

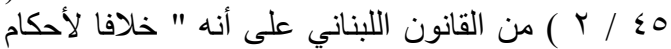

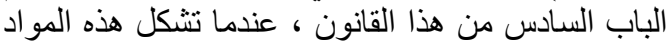

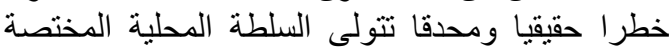

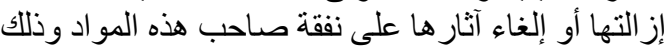

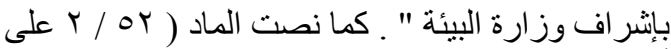

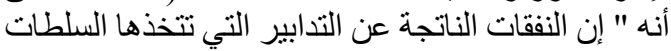

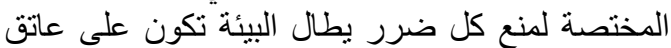

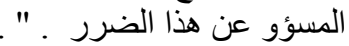

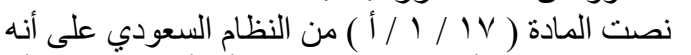

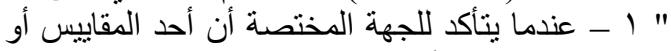

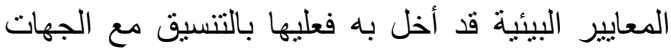

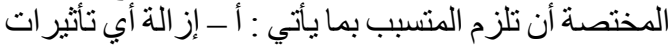

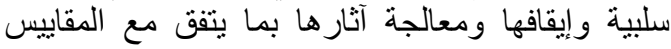

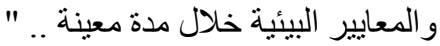

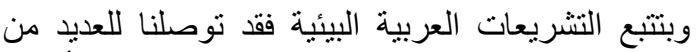
التدابير الاحتر ازية ، و التي تهذف إلى مو اجهة التصحر و أسبابه

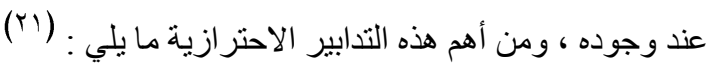

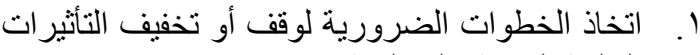

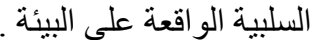

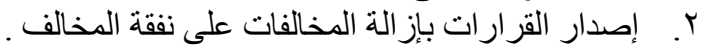

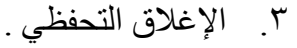

$$
\text { الفرع الر ابع: سياسة تجريم أسباب التصحر }
$$

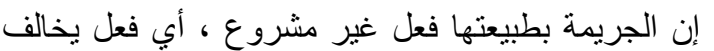

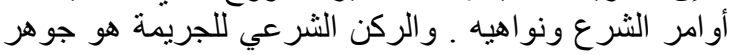

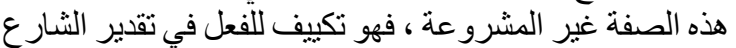

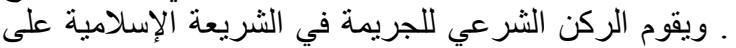

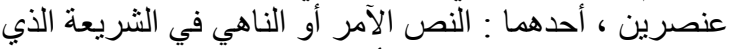

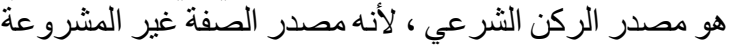

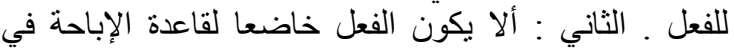

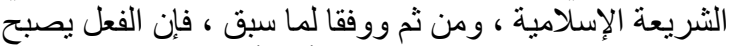

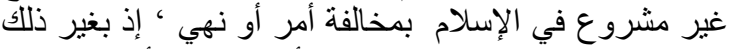

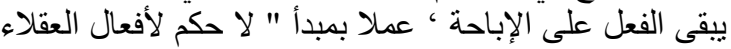

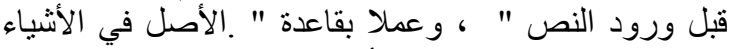

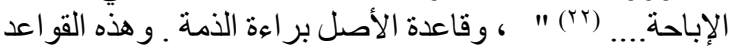

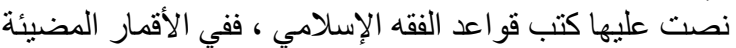

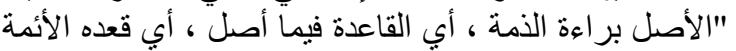

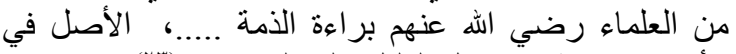

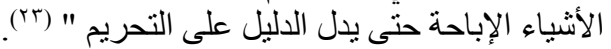

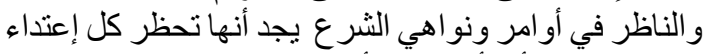

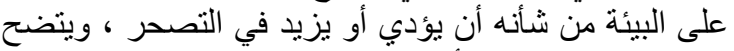
ذللك من خلال عموم الأدلة التالية :

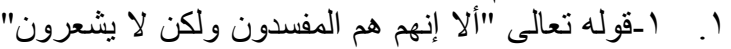
( $(\Upsilon)$

r. قوله تعالى " لا يريدون علو ا في الأرض و لا فسادا "(ro)،

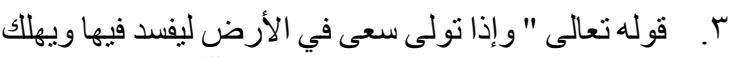

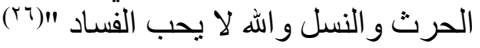

ع. قوله تعالى " ظهر الفساد في البر والبحر بما كسبت أيدي لأل الفي

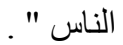

و المحافظة على الثروات و الموارد الطبيعية واستمر ار صلاحية

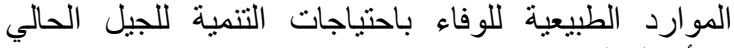
و الأجيال القادمة " الطوية ل

وفي ذات السياق نصت المادة ( ع ) ) من القانون اللبناني على الطى الطي

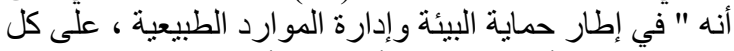
شخص طبيعي أو معنوي عام أو خاص إل أن يلتزم بالمبادئ الآتية

أ - مبدأ الاحتر اس ، و الذي يقضي باعتماد تدابير فعالة ومناسبة

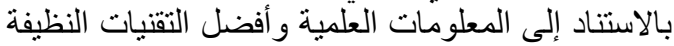

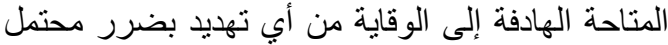

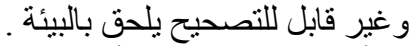
ب - مبدأ العمل لوقائي لكل الأضر ار التي تصيب البئة التئة .........

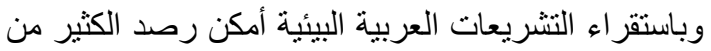

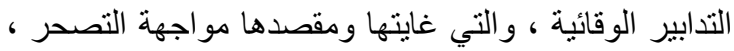

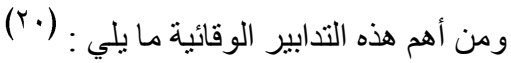

ا. إعداد المواصفات والمعايير القياسية لعناصر البيئة ومكوناتها . أنوان.

Y. مراقبة وقياس عناصر البيئة ومكوناتها ومتابعتها من خلال المر اكز العلمية.

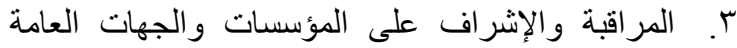
و الخاصة لضمان الالتز ام بالمو اصفات الضئ القياسية .

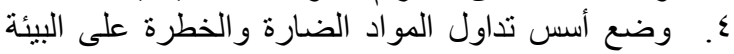

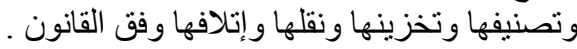
○. إعداد خطط طوارئ لمواجهة كوارث البيئة .

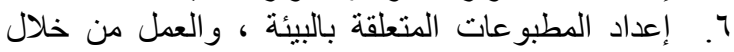

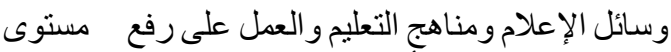

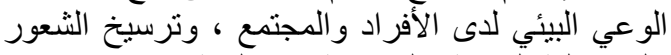
بالمسؤولية الفردية ولئي الجماعية تجاه البيئة .

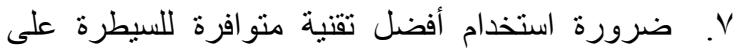

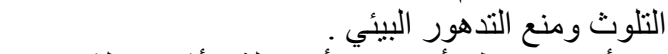
^. منع أو تقنين قطع أو اقتلاع أو إز الة الأشجار الثجيرات

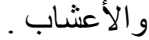
9. حق التفتيش ودخول المراب افق والمشاريع وأخذ العينات

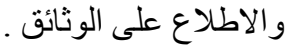

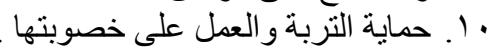

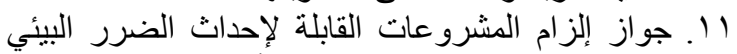

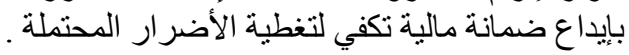

الفرع الثالث: التدابير الاحتر ازية للحماية من التصحر

ومن النصوص الواردة في هذا الصدد على سبيل المثال ما

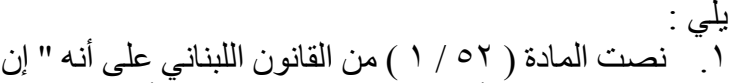

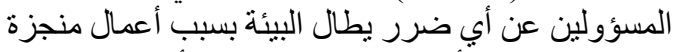

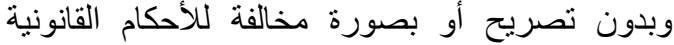

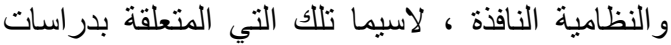

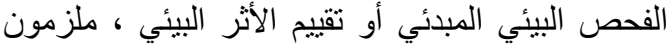

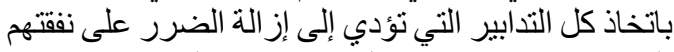

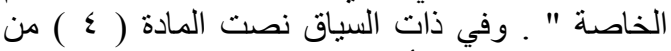

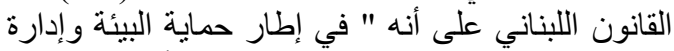

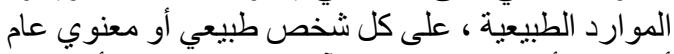

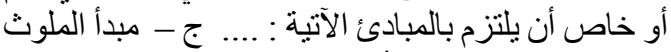

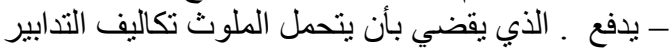


الجريمة زجر في نفسه وليردع غيره ، فالعقوبات موانع قبل

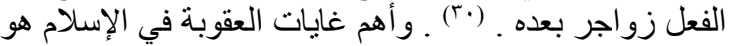

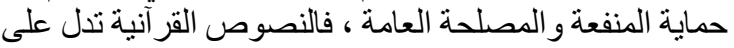

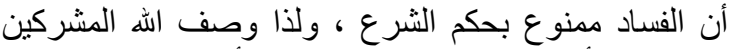

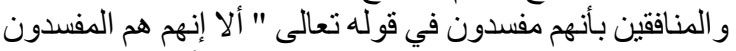

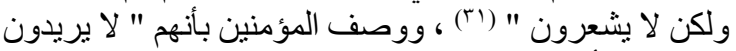

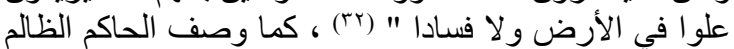

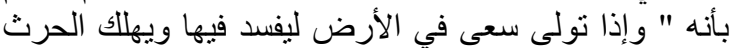

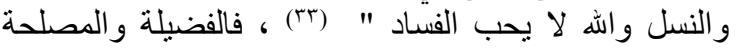

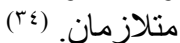

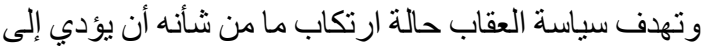

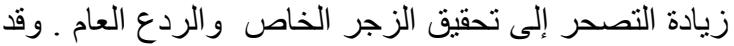

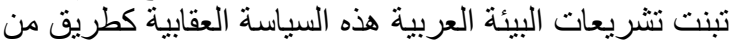

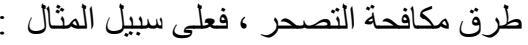

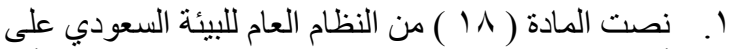

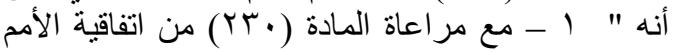

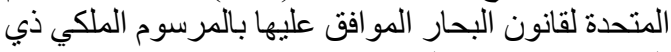

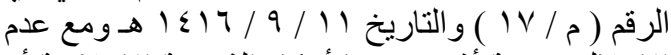
الإخلال بعقوبة أثند تقررها أحكام الثريعة الإسلامية أو ألمام

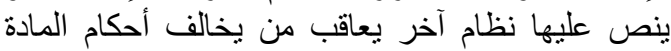

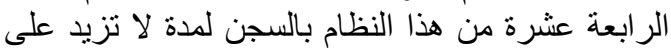

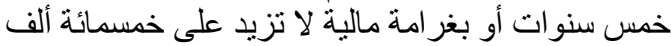

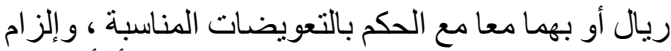

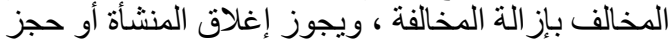

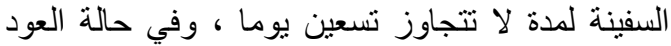

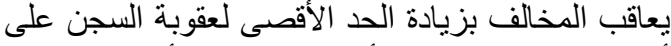

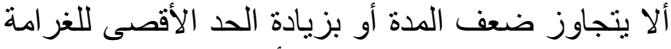

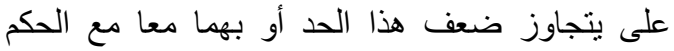

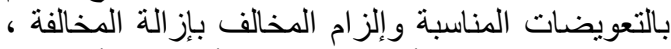
ويجوز إغلاق المنشأة بصفة مؤقتة أو دائمة أو حجز

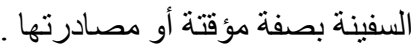

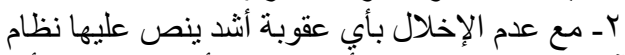

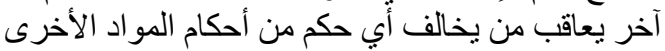

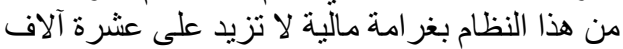

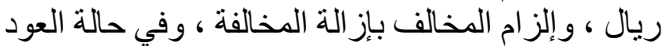

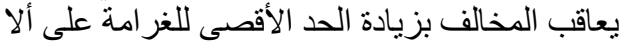

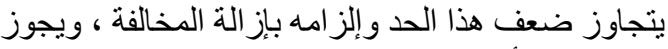

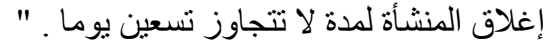

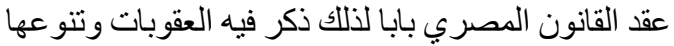

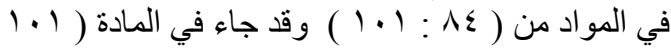

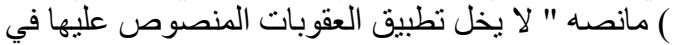
هذا الباب بتوقيع أية عقوبة أنثد مصوص لات عليها في قانون

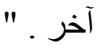

وبالنظر في النصوص السابقة وغير ها من نصوص العقاب

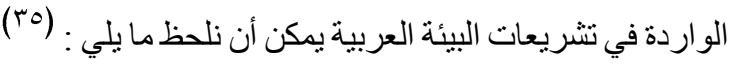

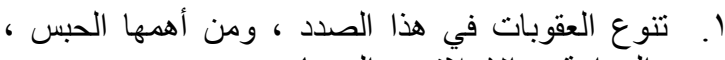

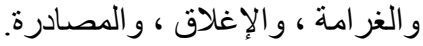

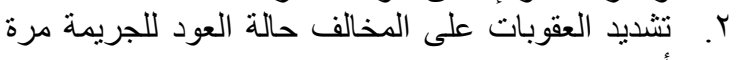

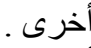
r. أن العقوبات تطال الفاعل للجرم وشركائه. . ع. أن العقوبة تقع على الثخص الإعنباري ومن يمثله

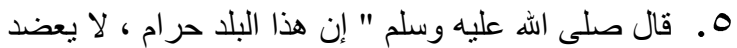
شوكه ، و لا يختلى خلاه ، و لا ينفر صيده ، و ولا تلتقط لقطته

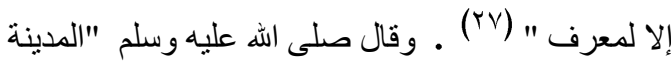

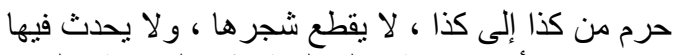
حدث ، من أحدث حدثا فعليه لعنة الله و الملائكة و الناس

$$
\text { أجمعين" (r^) ) }
$$

التشريعات البئية العربية وتجريم أسباب التصحر .

لقد استقرت التقنينات الجنائية الحديثة على مبدأ شرعية

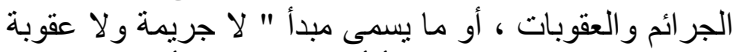

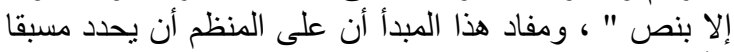

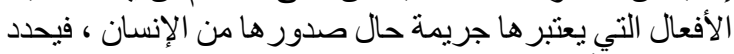

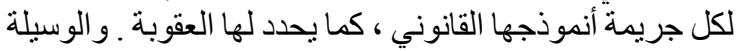

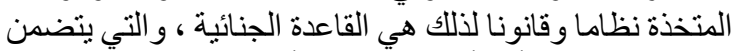

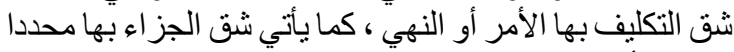

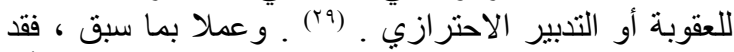

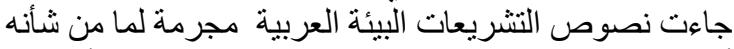
أن يعتبر إعتداء على البيئة ويؤدي إلى التصحر ، ومن أهم هذه

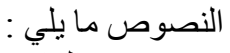

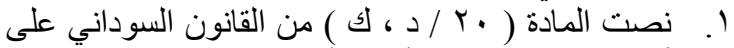

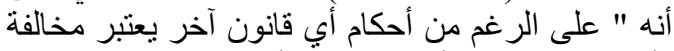
لأحكام هذا القانون أي فعل من الأفعال الآتية :

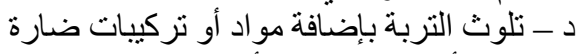

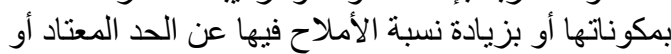
بإبلقاء القاذور اتيات و المو اد الطبيعية و الصناعية الضارة

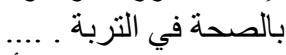

كـ - الإز التة والقطع للأشجار و التعدي على الغطاء

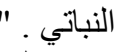

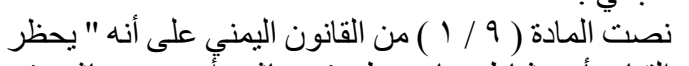

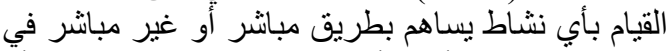

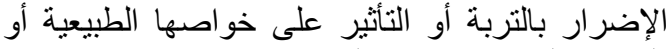

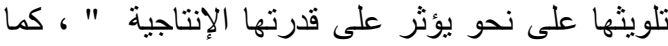

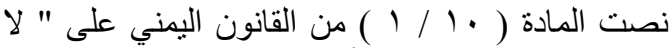

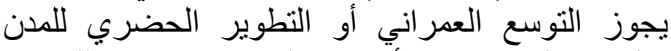

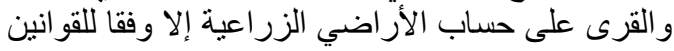

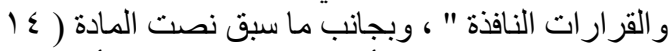

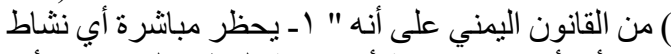

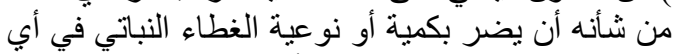

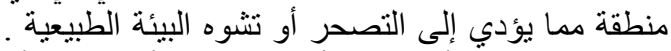

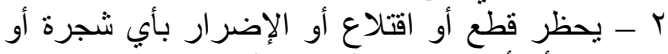

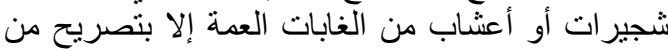

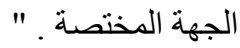
طبقا للمادة ( 11 / أ / / 1 ) من القانون الأردني يحظر

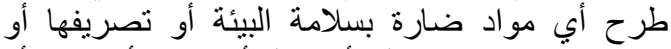
تجميعها سو اء كانت صلبة أو سائلة أو غازية أو مشعة أو أو أو أو أو أو حرارية في مصادر المياه ..." . الفرع الخامس: سياسة عقاب المخالفين

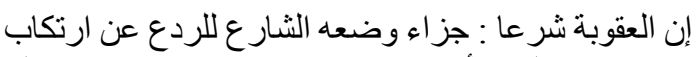

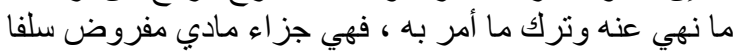
يجعل المكلف يحجم عن ارتكاب الجريمة ، فإن خالف وارئ مارتكب 
تقصيرية ـ (^^)" ـ وثمة نصوص قد وردث في القو انين البيئية

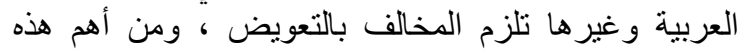

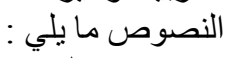

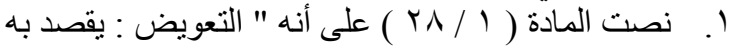

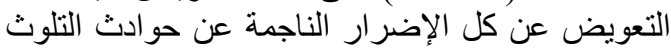

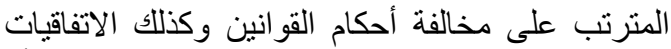

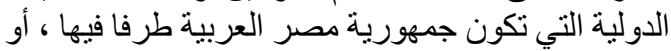

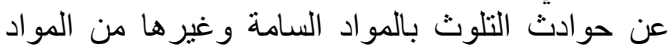

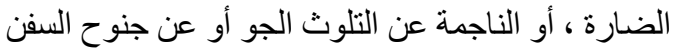

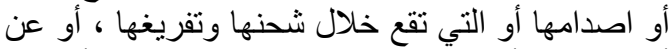

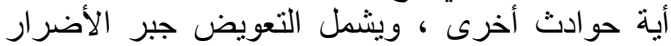

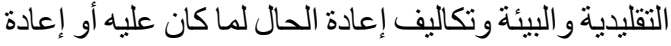

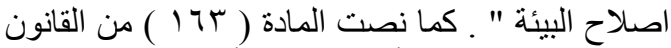

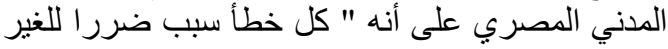

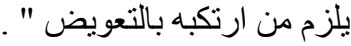

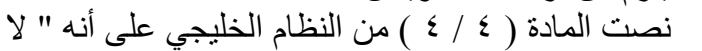

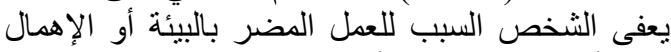

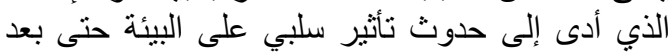

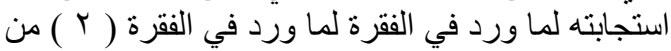
هذه المادة من مسؤولية الضرر الفئرة الذي لحق لحق بالبيئة نتيجة

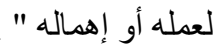

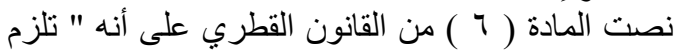

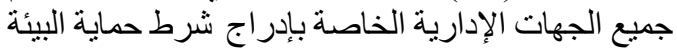

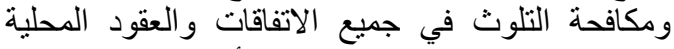

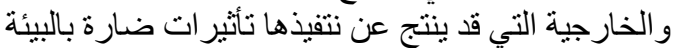

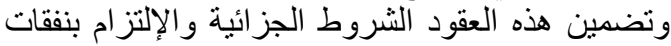

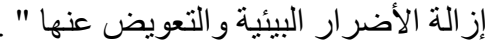

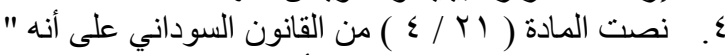

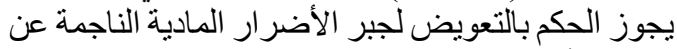

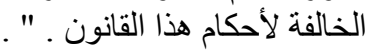

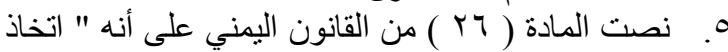

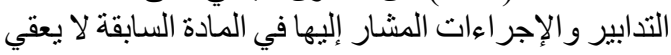

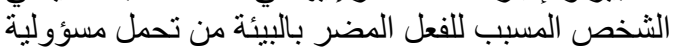

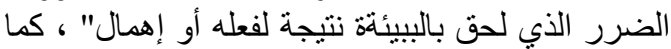

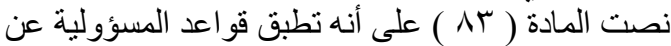

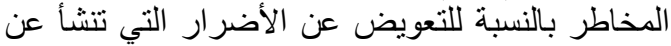
المواد الملوثة للبيئة وفقا لأحكام الثرئة الثريعة الإسلامية

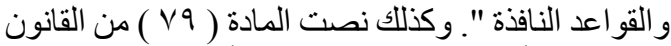

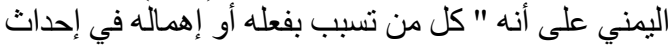

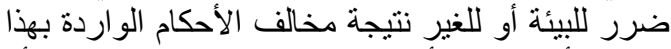

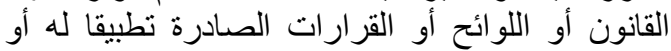

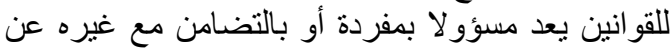

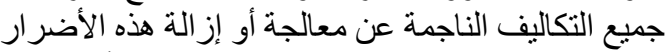

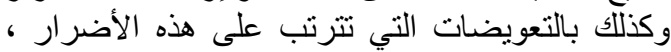

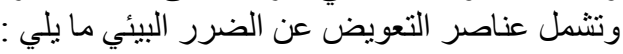
ا و. تكلفة إز الة الضرر البيئ وتنقية البئة

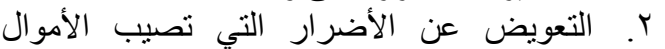

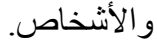

r. التعويض عن الأضرار التي تصيب البيئة ذاتها

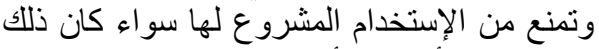

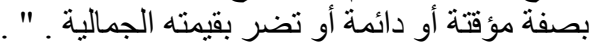
ومن خلال هذه النصوص تتضح أركان المسؤولية

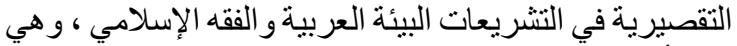
الخطأ ، و الضرر ، و و علاقة السببية كما يلي : 1 - الخطأ أو التعدي الضرد و عل
الفرع السادس: حق الإبلاغ ورفع الدعوى

وقد أعطى الإسلام للشخص الحق في رفع الدعوى حالة

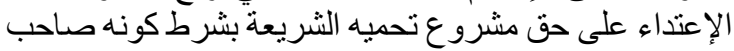

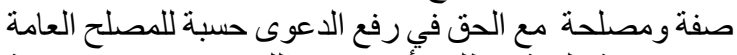

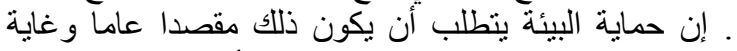

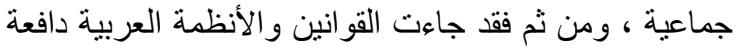

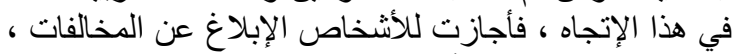

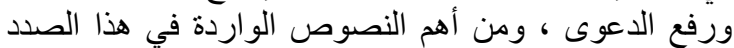

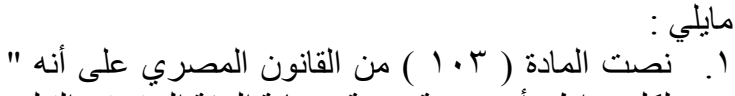

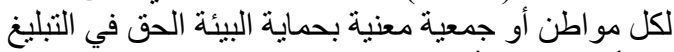

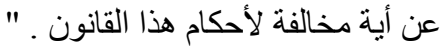

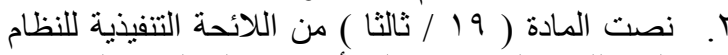

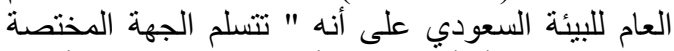
بلاغات التلوث أو أي بلاغي عات ألخات أخرى تنتعلق بمخالف أحكام

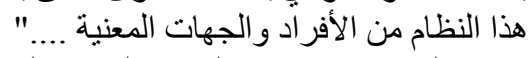

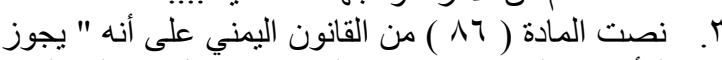

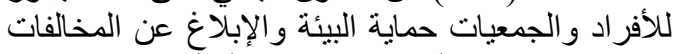

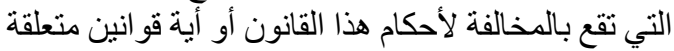

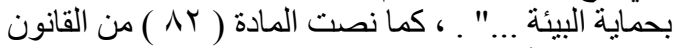

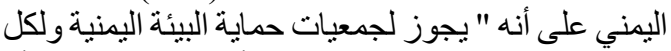

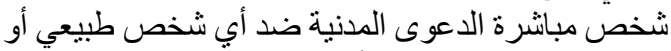

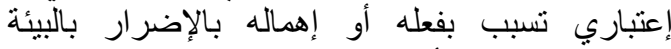

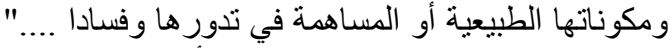

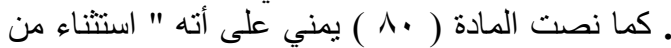

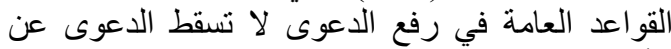

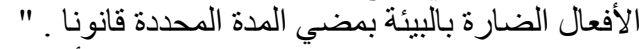

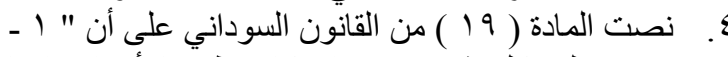

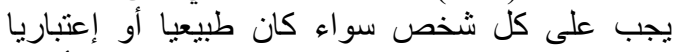

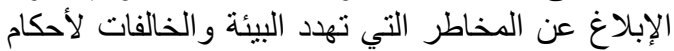

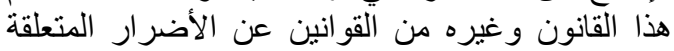

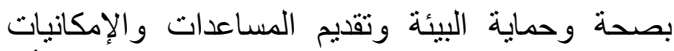

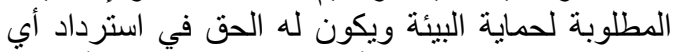

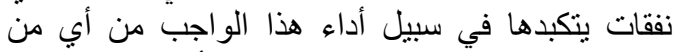

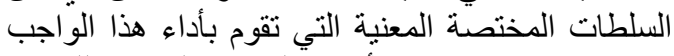

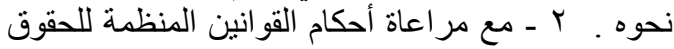

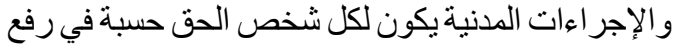

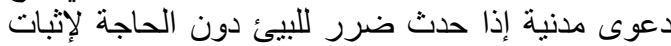

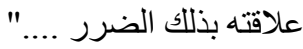

$$
\text { الفرع السابع: التعويض عن الأضرار البيئية }
$$

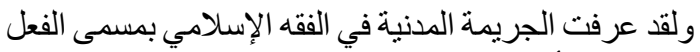

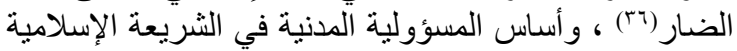

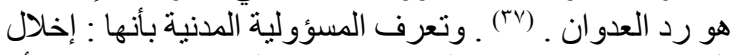

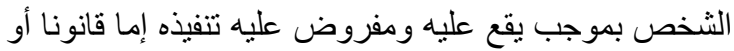

$$
\text { أركان المسؤولية المدنية قانونا وفقها }
$$

وتقوم المسؤولية المدنية حالة إخلال الثخص بالتز ام مقرر

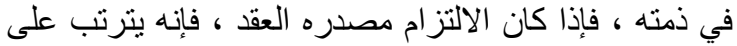

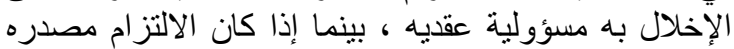
القانون والتعليمات ، فإنه يترتب عله على الإخلان بانه مسؤولية 


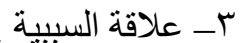

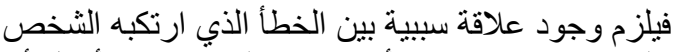

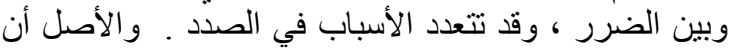

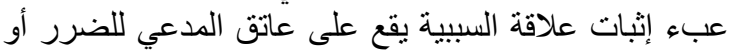

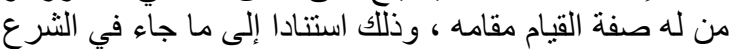

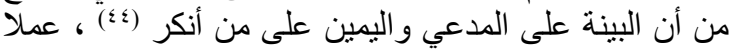

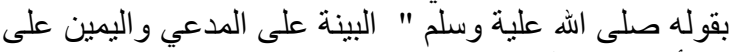

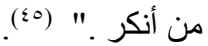

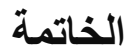

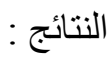

ثمة نتائج أسفر عنها البحث أهمها ما يلي :

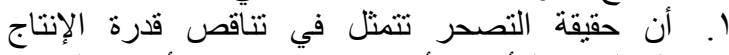

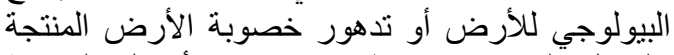
بالمعدل الذي يكسبها ظروف تشبه الأحور الإل المناخية

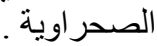
r. أن ثمة استقر اء بوجود تشريعات و هيئات ومؤسسات تشريعية وتنفيذية في العالم العربي تعمل على حماية البيئة

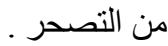
r. أن التشريعات العربية قد جاءت بتدابير وقائية وأخرى الترى احترازية للحماية من التصحر ومحاولة معالجة الجة الأمر عند

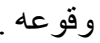
ع. أن الشريعة الإسلامية ، وكنلك القانون قد كفلا بقدر كبير

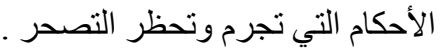

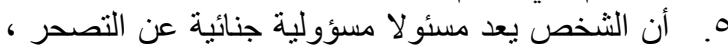

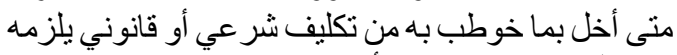

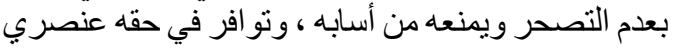
المسؤولية الجنائية ، وهما التمييز ، و القدرة على الاختيار

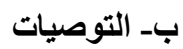

تتمثل أهم التوصيات فيما يلي :

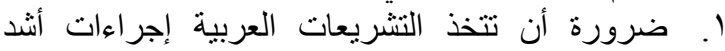
صر امة لنع جريمة التصحر و العمل على حماية البيئة .

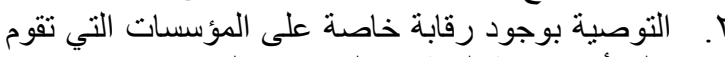

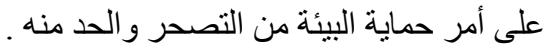

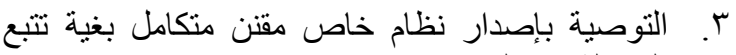

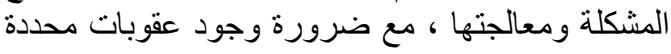

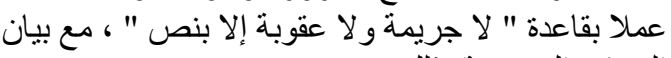

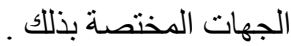
ع. أن يكون للمؤتمر صفة الدورية .

المراجع

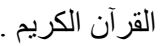

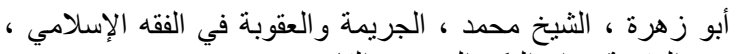
العقوبة ، دار الفكر العربي ، القاهرة .

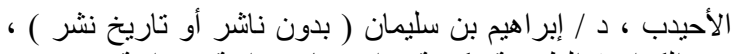

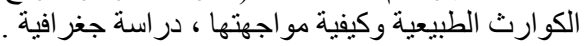

و الفعل الضار شر عا هو : كل فعل حسي ترتب عليه ضرر

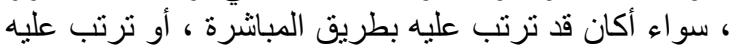

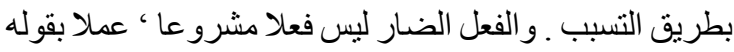

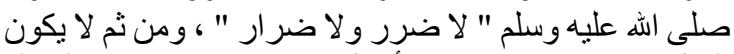

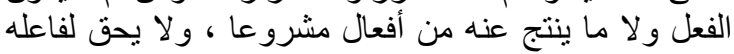

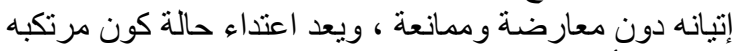

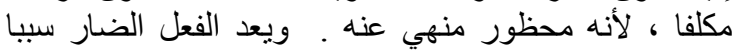

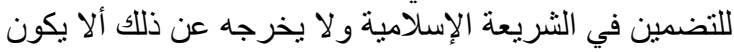

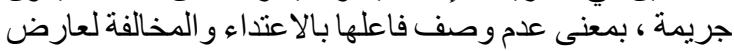

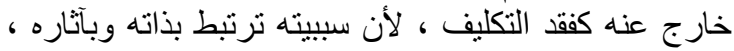
وليس بقصد فاعله . (ra) وقد تعددت الآراء حول تحديد فكرة الخطأ في المسؤولية

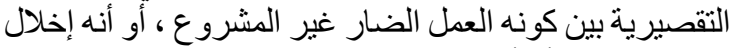

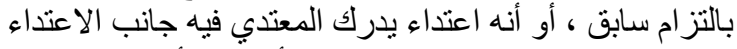

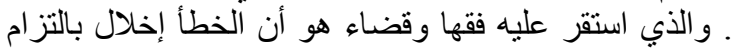

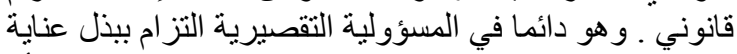

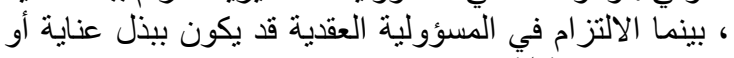

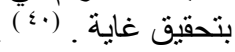
ويتحقق وجود الخطأ في المسؤولية التقصيرية بوجود التعدي

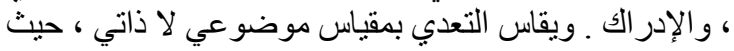

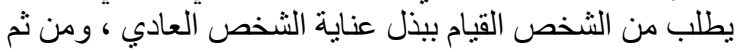

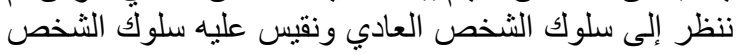

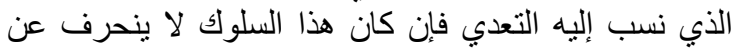

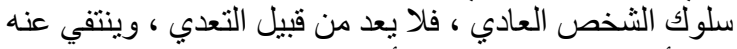

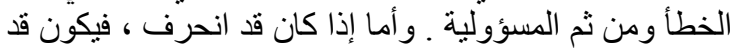

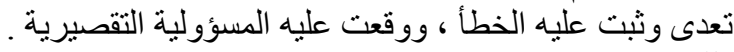

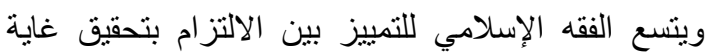

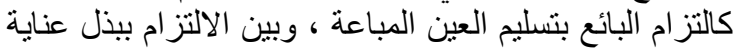

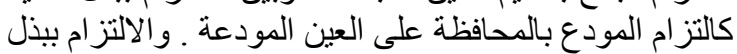

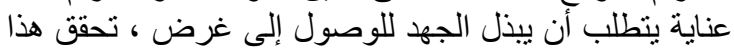

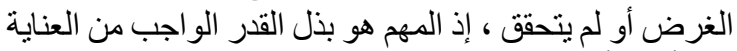

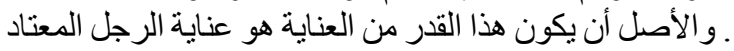

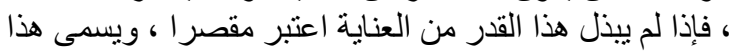

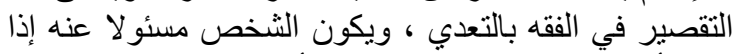

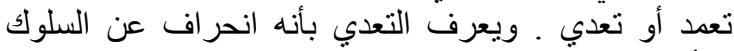

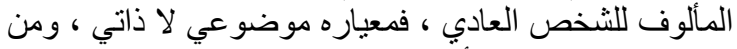

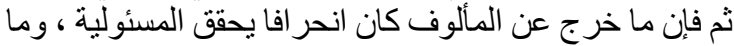
كان في إطار المعتاد لا يكون تعديا ، ومن ثم لا يوجن الض الضمان الضمان (\&r).

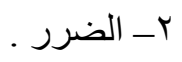

يعرف الضرر بأنه " كل فعل يصيب الإنسان يسبب له له

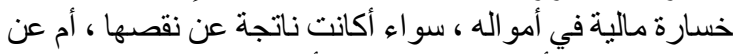

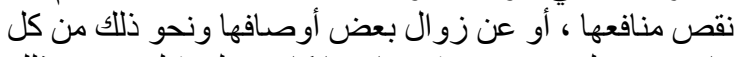

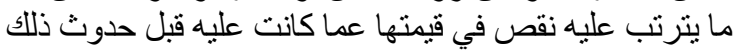

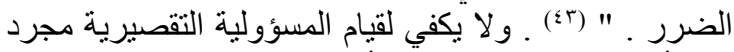

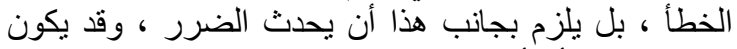

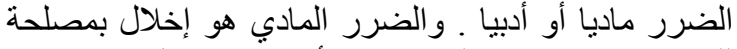

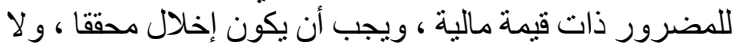

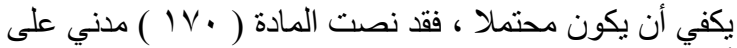

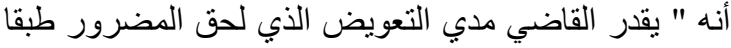

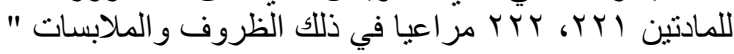




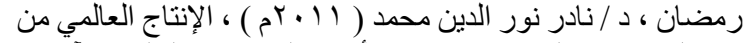

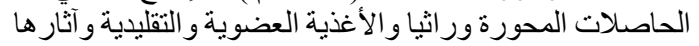

على الفجو الغذائية العربية ، مكتبة جزيرة الأية الوغرية الورد ، القاهرة ،

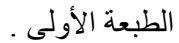

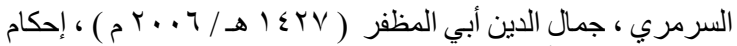

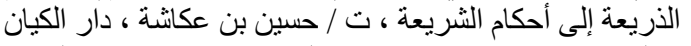

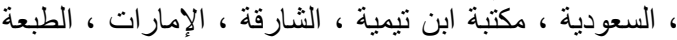

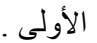

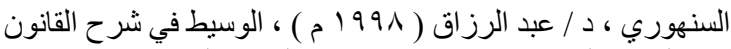

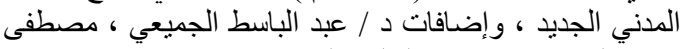

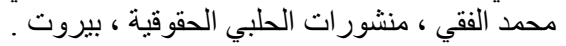

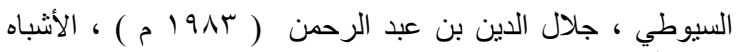
و النظائر . جالر

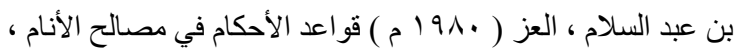

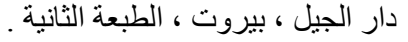

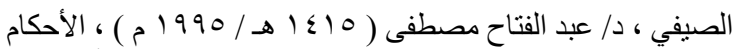

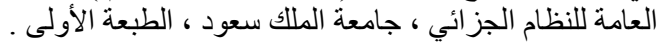

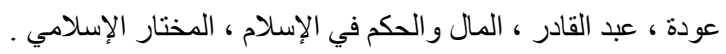

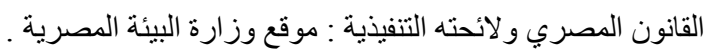
http://www.eeaa.gov.eg/arabic

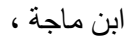

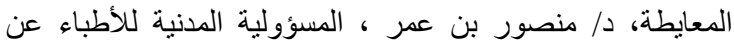

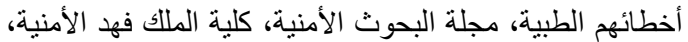

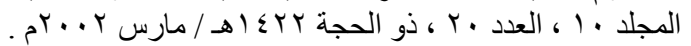

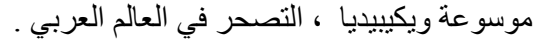

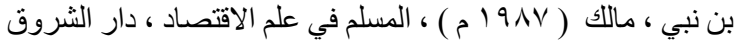

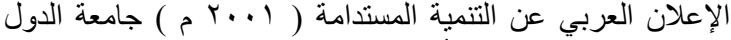

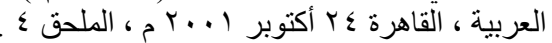

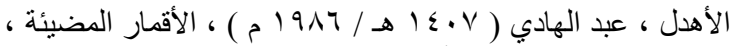

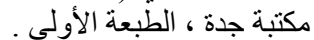

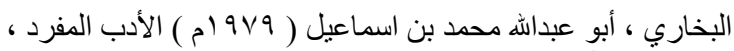

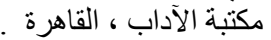

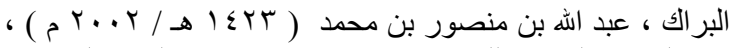

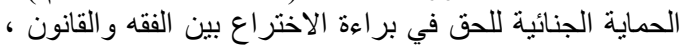

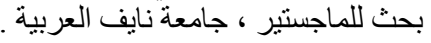

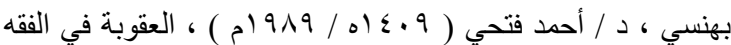

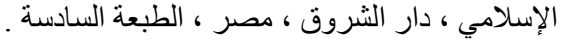

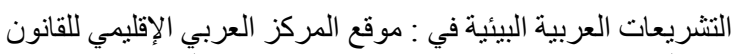
البيئي

http://arcel.kuniv.edu.kw/index.php?option=co $\mathrm{m}$ تقرير التنمية ( 199 1 م ) البنك الدولي .

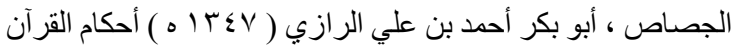

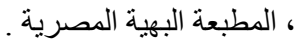

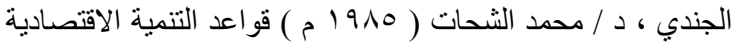

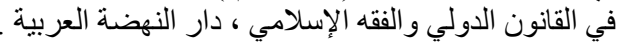

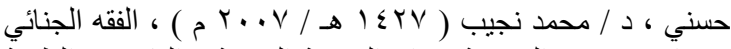
الإسلامي ، الجريمة ، دار النهضة العربية ، القاهرة ، الطبهة ، الطبّة

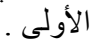

خان ، صديق ، ( 1970 ) ) ، فتح البيان في تفسير القرآن ، مطبعة

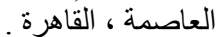
الخفيف ، الثيخ علي ( 199 ( م ) ، الضمان في الفقه الإسلامي ، دار الفكر العربي، مصر . 